ISSN : 2550-0198

\title{
PERWUJUDAN KELUARGA SAKINAH MELALUI PENGELOLAAN KEUANGAN RUMAH TANGGA SECARA ISLAMI
}

\author{
Evi Marlina*, Muhammad Ahyaruddin, Zul Azmi, Adriyanti Agustina Putri, \\ Della Hilia Anriva, Isran Bidin, Agustiawan, Siti Masitoh Sinaga, Nadia \\ Fathurahmi Lawita. \\ Prodi Akuntansi, Fakultas Ekonomi dan Bisnis UMRI \\ Universitas Muhammadiyah Riau \\ *Email : evimarlina@umri.ac.id
}

\begin{abstract}
Abstrak
Keluarga Sakinah merupakan dambaan setiap orang dalam membina rumah tangga. Realitanya impian tidak seindah kenyataan banyak keluarga yang baru hitungan tahun, bulan dan hari sudah masuk kejenjang perceraian. Banyak faktor yang menyebabkan hal tersebut berdasarkan data statistik dipengadilan agama kota Pekanbaru faktor yang dominan adalah faktor ekonomi. Dengan demikian perlunya suatu pengetahuan bagaiman kita pengelolaan keuangan rumah tangga secara islami yang sesuai dituntunan al quran dan hadist. Pengabdian ini dilakukan untuk meningkatkan pemahaman pengelolaan keuangan keuangan rumah tangga secara islami. Kegiatan ini dilakukan di mesjid Istiqlal Kelurahan Sidomulyo Timur, Kecataman Marpoyan Damai, Kota Pekanbaru. Pendekatan yang dilakukan adalah ceramah dan diskusi, yaitu dengan memberikan penjelasan materi secara tutorial dan diskusi serta memberikan contoh pembahasan permasalanpermasalahan yang ada yang sesuai dengan tuntutunan agama.
\end{abstract}

Kata kunci: Keluarga Sakinah, Pengelolaan Keuangan, Secara Islami

\section{PENDAHULUAN}

Harta dalam Islam merupakan amanah dan hak milik seseorang. Kewenangan untuk menggunakannya terkait erat dengan adanya kemampuan (kompetensi) dan kepantasan (integritas) dalam mengelola aset atau dalam istilah prinsip kehati-hatian perbankan (prudential principle). Prinsip Islam mengajarkan bahwa "Sebaik-baik harta yang shalih (baik) adalah dikelola oleh orang yang berkepribadian shalih (amanah dan profesional)."

Hak bekerja dalam arti kebebasan berusaha, berdagang, memproduksi barang maupun jasa untuk mencari rezki Allah secara halal merupakan hak setiap manusia tanpa diskriminasi antara laki dan perempuan. Bila kita tahu bahwa kaum wanita diberikan oleh Allah hak milik dan kebebasan untuk memiliki, maka sudah semestinya mereka juga memiliki hak untuk berusaha dan mencari rezki.

Rasulullah shallallahu 'alaihi wa sallam memuji seseorang yang mengkonsumsi hasil usahanya sendiri dengan sabdanya: "Tidaklah seseorang mengkonsumsi makanan lebih baik dari mengkonsumsi makanan yang diperoleh dari hasil kerja sendiri, sebab nabi Allah, Daud, memakan makanan dari hasil 
kerjanya." (HR. Bukhari). "Semoga Allah merahmati seseorang yang mencari penghasilan secara baik, membelanjakan harta secara hemat dan menyisihkan tabungan sebagai persediaan di saat kekurangan dan kebutuhannya." (HR. Muttafaq 'Alaih).

Hal ini menunjukkan bahwa Islam menghendaki setiap muslim untuk dapat mengelola usaha dan berusaha secara baik, mengelola dan memenej harta secara ekonomis, efisien dan proporsional serta memiliki semangat dan kebiasaan menabung untuk masa depan dan persediaan kebutuhan mendatang. Prinsip ini sebenarnya menjadi dasar ibadah kepada Allah agar dapat diterima (mabrur) karena saran, niat dan caranya baik. Rasulullah shallallahu 'alaihi wa sallam bersabda: "Sesungguhnya Allah itu baik dan hanya menerima yang baik-baik saja." (HR. Muslim).

Kesadaran akuntabilitas (ma'uliyah) dalam bidang keuangan itu yang mencakup aspek manajemen pendapatan dan pengeluaran timbul karena keyakinan adanya kepastian audit dan pengawasan dari Allah subhanahu wa ta'ala seperti sabda Nabi shallallahu 'alaihi wa sallam: "Kedua telapak kaki seorang hamba tidak akan beranjak dari tempat kebangkitannya di hari kiamat sebelum ia ditanya tentang empat hal, di antaranya tentang hartanya; dari mana dia memperoleh dan bagaimana ia membelanjakan.” (HR. Tirmidzi)

\section{Permasalahan}

Dari penjelasan di atas dapat diungkapkan beberapa masalah yang umumnya dihadapi oleh pihak mitra terkait dengan pengelolaan keuangan mesjid, yaitu:
a. Tidak menetapkan skala prioritas keuangan rumah tangga
b. Tidak seimbangnya pendapatan dan pengeluaran,
c. Pengeluaran yang tidak terencana dengan baik
d. Tidak mencatat dan mengatur cashflow keuangan rumah tangga

\section{Tujuan Kegiatan dan rencana pemecahan masalah}

Kegiatan pengabdian ini bertujuan untuk: (1) meningkatkan kesadaran masyarakat (jamaah) tentang pentingnya menentukan skala proritas dalam pengelolaan keuangan rumah tangga, (2) memberikan pemahaman tentang pentingnya menjaga keseimbangan antara pemasukan dan pengeluaran rumah tangga (3) memberikan pengetahuan tentang perlu perencanaan yang matang setiap pengeluaran baik yang rutin seperti belanja bebutuhan rumah tangga sehari-hari dan pengeluran non rutin seperti pembelian peralatan rumah tangga, liburan dan lain-lain, dan (4) meberikan pelatihan tentang pencatatan pemasukan dan pengeluaran kas secara sederhana

\section{METODE PENGABDIAN}

\section{Tempat dan Waktu}

Kegiatan pengabdian masyarakat tentang manajemen pengelolaan keuangan mesjid ini dilaksanakan di Mesjid Istiqlal Kelurahan sidomulyo Timur Kecamatan Marpoyan Damai Kota Pekanbaru pada hari Sabtu tanggal 19 Agustus 2017. 
ISSN : 2550-0198

\section{Ruang Lingkup dan Objek Pengabdian}

Objek yang menjadi sasaran dari kegiatan pengabdian ini adalah jamaah majlis taklim yang ada di mesjid Istiqlal kelurahan Sidomulyo Timur. Mereka yang menjadi sasaran ibu-ibu rumah tangga sebagai pihak yang bertanggungjawab terhadap pengelolaan keuangan keuangan rumah tangga

\section{Pendekatan atau teknik pengabdian}

Kegiatan pengabdian ini dilakukan dengan menggunakan pendekatan ceramah dan diskusi kepada jamaah majlis taklim mesjid istiqlal tentang pengelolaan keuangan rumah tangga. Adapun langkah-langkah yang dilakukan yaitu: 1) Tahap meningkatkan pengetahuan pengelolaan keuangan rumah secara islami, dan 2) Tahap pengelolaan keuangan secara islami dalam mewujudkan keluarga sakinah.

\section{HASIL DAN PEMBAHASAN}

\section{Pelaksanaan Kegiatan}

Kegiatan pengabdian masyarakat ini diawali dengan persiapan pelaksaan kegiatan, yaitu persiapan tim dengan melakukan rapat koordinasi, pembuatan surat undangan, penyebaran undangan kepada pengurus majlis taklim mesjid Istiqlal dan majlis taklim mesjid Darul Amal kelurahan Sidomulyo Timur, dan kegiatan ceramah dan diskuis bagi ibu-ibuk majlis taklim yang merupakan ibu-ibu rumah tangga. Dari undangan yang disebarkan, dua majlis taklim tersebut mengkonfirmasi kesediaan mereka hadir sebagai peserta.
Kegiatan selanjutnya adalah persiapan kelengkapan kegiatan yang meliputi hal-hal sebagai berikut:

1. Mempersiapkan tempat pelaksanaan ceramah dan diskusi, yaitu Mesjid Istiqlal

2. Mempersipkan media presentasi, yaitu slide presentasi dan Infocus/LCD

3. Pembuatan modul yang akan digunakan dalam ceramah dan diskusi. Modul tersebut dibuat oleh pemateri dengan cakupan berupa materi-materi yang akan diberikan dalam ceramah dan diskuis. Modul tersebut dibuat dalam bentuk tutorial, teori dan contoh pengelolaan keuangan rumah tangga secara Islami

Dalam kegiatan ceramah dan diskusi tersebut, hanya satu orang pemateri yang memberikan penjelasan tentang pengelolaan keuangan rumah tangga secara islami. Materi berupa penjelasan tentang konsep keluarga sakinah, bagaimana membentuk keluarga sakinah, pengelolaan keuangan rumah tangga secara islami sebagai perwujudan keluarga sakinah serta permasalahanpermasalahan yang selama ini sering dihadapi oleh sebagian rumah tangga sehingga perlu adanya pengelolaan keuangan secara islami.

Ceramah dan diskusi diberikan selama lebih kurang dua jam dimana ceramah kurang lenih selama satu setengah jam kemudian dilanjutkan dengan diskusi antara peserta dengan pemateri. Pada sesi diskusi, para peserta terlihat sangat antusias dengan menyampaikan pertanyaanpertanyaan terkait dengan permasahan yang selama ini mereka hadapi dalam rumah tangga mereka. Sesi diskusi ini memberikan ruang 
dan suasana kedekatan antara peserta dan panitia maupun pemateri. Banyak peserta yang menyampaikan saran kepada panitia agar kegiatan seperti terus dilakukan dalam rangka untuk meningkatkan pemahaman pengelolaan keuangan rumah tangga secara islami dan tema-tema lain yang menambah wawasan para ibu-ibu rumah tangga agar dapat mewujudkan keluarga sakinah.

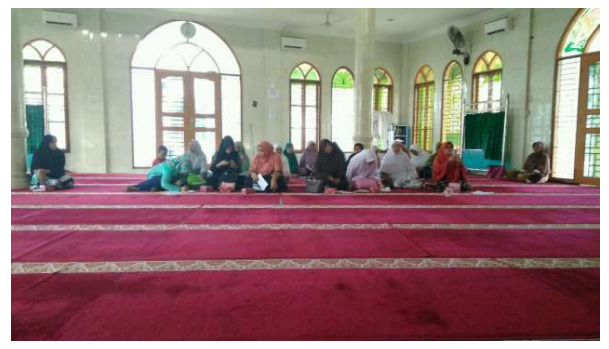

Gambar 1. Peserta Pelatihan

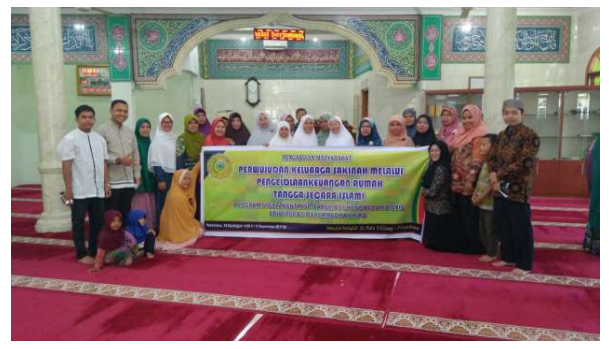

Gambar 2. Foto Bersama Peserta

Pada akhir kegiatan, para peserta dan panitia berfoto bersama untuk mengabadikan kegiatan yang dilakukan serta diakhiri dengan makan bersama.

\section{SIMPULAN}

Kesimpulan dari kegiatan pengabdian masyarakat bagi ibu-ibu majlis taklim mesjid Istiqlal dan menjid Darul Amal adalah sebagai berikut.

Peserta pelatihan sangat antusias ketika mengikuti ceramah dan diskusi. Para peserta dapat melihat manfaat ceramah ini, yakni menambah pengetahuan pada bidang pengelolaan rumah dalam perwujudan keluarga sakinah, khususnya pengelolaan keuangan.

Berdasarkan sharing yang dilaksanakan pada saat diskusi, tidak ada kesan buruk dari peserta selama pelaksanaan kegiatan, baik dari segi sarana dan prasarana maupun penyampaian materi, hanya saja perlu dibuat dalam skala yang lebih luas.

Pengabdian selanjutnya diarahkan pada sharing masalah pengeloaan keuangan tetapi dengan tema dan objek yang berbeda.

\section{UCAPAN TERIMAKASIH}

Penulis mengucapkan terima kasih dan apresiasi yang sebesar-besarnya kepada LPPM UMRI yang telah memberikan bantuan dana serta kepada pengurus mesjid Istiqlal yang telah membantu mensukseskan terlaksananya kegiatan pengabdian ini dengan lancar.

\section{DAFTAR PUSTAKA}

[1] Hendi Suhendi, Ramadhani Wahyu, S.Ag (2001). Pengantar Studi Sosiologi Keluarga. Bandug: Pustaka setia.

[2] Ligwina Hananti 2016, Seminar Sehari Pengelolaan Keuangan Rumah Tangga Secara Sederhana, Bandung. Prop DT. 1 Jabar Forum Studi Cendikiawan.Dewan Standar Akuntansi

[3] M. Quraish Shihab (2002). Tafsir Al-Mishbah juz 1-30 Jakarta: LenteraHati 